\title{
Aminotransferases Activity in the Hemolymph of Bradybaena similaris (Gastropoda, Xanthonychidae) under Starvation
}

\author{
Jairo Pinheiro $^{+}$, Edna Maria Gomes, Generoso Manoel Chagas \\ Departamento de Ciências Fisiológicas, Instituto de Biologia, Universidade Federal Rural do Rio de Janeiro, \\ 23851-970 Seropédica, RJ, Brasil
}

\begin{abstract}
Aminotransferases (GOT and GPT) activities in the hemolymph of Bradybaena similaris under experimental condition of starvation were studied. At the 10th day of starvation, GOT activity was $416.6 \%$ higher than that observed in the fed snails, being reduced and ranging values near to that shown by the control group onwards. GPT activity only varied significantly at the day-30 of starvation. The results were discussed.
\end{abstract}

Key words: Bradybaena similaris - snail - starvation - aminotransferases - L-aspartate:2oxoglutarate aminotransferase - L-alanine:2oxoglutarate aminotransferase

Aminotransferases, also called transaminases, constitute a group of enzymes that catalyzes the interconversion of amino acids in $\alpha$-keto acids by transferring amino groups (Moss \& Henderson 1998). The aminotransferases have an important role in the linking of the amino acids and carbohydrate metabolism, being an essential group of enzymes in the gluconeogenesis pathway. Beyond this, the aminotransferases are good indicators of tissue lesions.

Aminotransferase activity has been shown by some authors in the hemolymph of molluscs infected with larval trematodes (Manohar et al. 1972), in tissues of trematode-infected (Christie \& Michelson 1975) and uninfected snails (Nabih et al. 1990). The activity of these enzymes was also studied in starved snails (El-Emam \& Ebeid 1989).

Starvation is a physiological condition that resembles trematode infection. Starvation and trematode infection caused quantitative and qualitative changes in protein and carbohydrate levels in snails (Becker \& Schmale 1975, Becker \& Hirtbach 1975, Schmale \& Becker 1977, Stanilawsky \& Becker 1979a,b). Pinheiro and Amato (1994) observed a marked reduction in the glycogen deposits of Bradybaena similaris (Férussac, 1821) infected with Eurytrema coelomaticum (Giard et Billet, 1892) Looss, 1907 larva. This alteration was accompanied by a significant reduction of the glucose con-

\footnotetext{
${ }^{+}$Corresponding author. Fax: $+55-21-2682.1763$. E-mail: jps@ufrrj.br

Received 9 February 2001

Accepted 2 July 2001
}

centration in the hemolymph of the parasitized snails. Pinheiro (1996) observed that the starvation caused a similar reduction of the glycogen and galactogen deposits of $B$. similaris. Thirty days of starvation caused the same percentage of reduction as 140 days of E. coelomaticum infection. In response to these carbohydrate depletion caused by starvation, the snail uses other substrates to obtain the energy needed for its maintenance. Lira et al. (2000) observed that the total protein content in the hemolymph of $B$. similaris changes after a short period of starvation. Thus, aminotransferase activity in the starved snails must also be changed.

This study reports the changes in L-aspartate:2oxoglutarate aminotransferase (E.C.2.6.1.1) (GOT) and $\mathrm{L}$-alanine:2-oxoglutarate aminotransferase (E.C.2.6.1.2) (GPT) activities in the hemolymph of starved B. similaris.

\section{MATERIALS AND METHODS}

Snails collection and maintenance - Specimens of $B$. similaris were collected from gardens located at km 37.5, Avenida Brasil, Rio de Janeiro, RJ, Brazil and transported to Universidade Federal Rural do Rio de Janeiro. The snails were observed under stereomicroscope through their transparent shell to verify the presence of Phostarmostomum gallinum metacercariae in the pericardial cavity. A sample of the snails was randomly chosen and dissected to verify the presence of parasites in its tissues. Snails free of infections with $10 \mathrm{~mm}$ of shell diameter, were transferred to glass vivaria, with earth at the bottom and maintained under laboratory conditions $\left(25 \pm 3^{\circ} \mathrm{C}\right)$. They were fed with cabbage leaves (Brassica sp.) ad libitum and the vivaria earth was moistened with tap water on alternate days. 
Starvation and hemolymph collection - Groups of 50 snails were formed. The food supplies were suspended and the snails were only given tap water on alternate days. The snails were submitted to 0 (control group), 5, 10, 15, 20, 25 and 30 days of starvation. The hemolymph of at least 25 snails was collected by punction of the pericardial cavity using a syringe (B-D Plastipak ${ }^{\circledR}$ ) at $0^{\circ} \mathrm{C}$ and stored in microtubes at $-10^{\circ} \mathrm{C}$ until its utilization.

Biochemical analysis - Aminotransferases, GOT and GPT, activities in the hemolymph of starved B. similaris were determined by the method of Reitman and Frankel (1957) according to bioMérieux. The results were expressed as URF/ $\mathrm{ml}$.

Statistical analysis - The results obtained were expressed by mean and standard deviation and submitted to polinomial regression and TukeyKramer multiple comparison test $(\alpha=5 \%)$.

\section{RESULTS}

The GOT activity in the control group was 19.367 URF/ml (Table). In starved snails, there was an increase in the GOT activity at 10th day of starvation, being $100.05 \mathrm{URF} / \mathrm{ml}$, which represents an activity $416.6 \%$ higher than that observed in the control snails. But, after this period of starvation GOT activity was reduced, ranging values near to that observed in fed snails, being the lowest value observed at 30 days of starvation, when the activity was $8.1 \%$ lower than that observed to control group.

The polinomial regression test showed a negative relation between the time of starvation and the GOT activity in the hemolymph of $B$. similaris, but this relation was not very significant $\left(r^{2}=0.56\right)$ (Fig. 1).

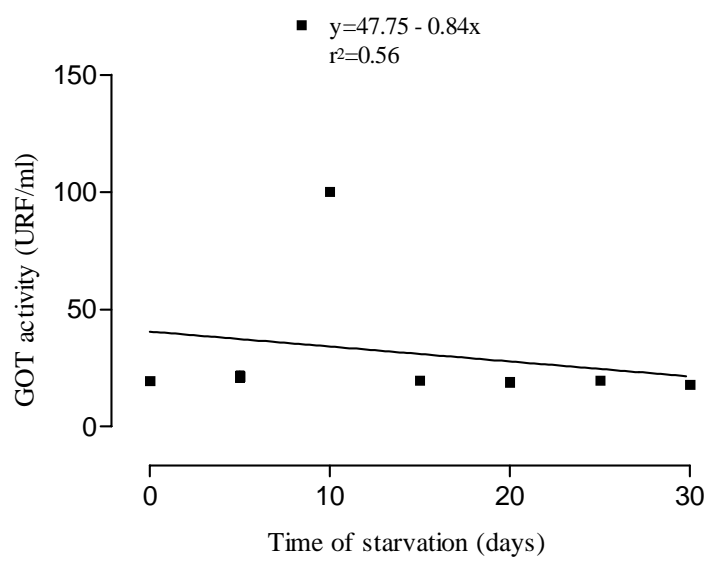

Fig. 1: the negative relation between the L-aspartate:2oxoglutarate aminotransferase (GOT) activity, expressed im URF/ml, in the hemolymph of Bradybaena similaris and the time of starvation, expressed in days.
The GPT activity did not vary so markedly as GOT (Table). The mean value observed at 30 days of starvation was significantly different and higher than that observed at 10,15 and 25 days of starvation, but it was not different from the activity observed in the control snails. The polinomial regression test showed a positive relation between the time of starvation and the GPT activity in the hemolymph of B. similaris (Fig. 2), but this relation was also weakly significant $\left(\mathrm{r}^{2}=0.63\right)$.

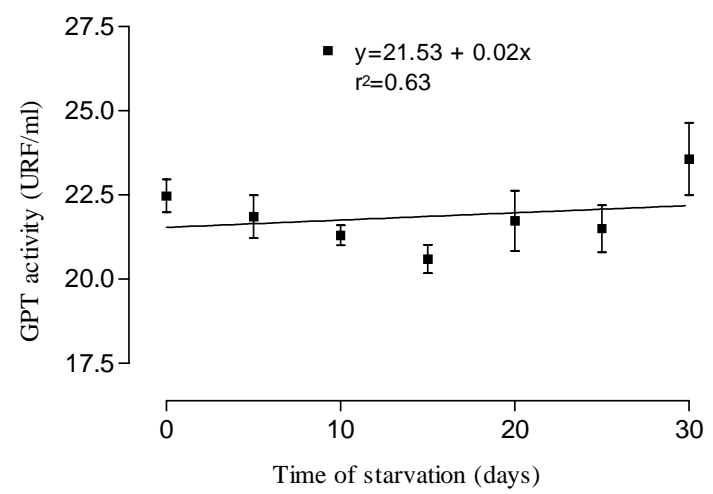

Fig. 2: the negative relation between the L-aspartate:2oxoglutarate aminotransferase (GPT) activity, expressed im URF/ml, in the hemolymph of Bradybaena similaris and the time of starvation, expressed in days.

\section{DISCUSSION}

The snails use carbohydrates as the main source of energy for their metabolic processes of maintenance and reproduction, being these substances stored as polysaccharides, as glycogen and galactogen, in tissues of the digestive gland, cephalopedal mass and albumen gland. When the snails are exposed to conditions of stress, such as parasitism by larval trematodes and starvation, other substrates may be used for the same objective (Joosse \& Van Elk 1986).

In the snail B. similaris, starvation causes a depletion of the glycogen and galactogen reserves (Pinheiro 1996). Lira et al. (2000) observed an increase in the total protein concentration in the hemolymph of $B$. similaris at day 10 of starvation, when this value was $198 \%$ higher than that observed in the hemolymph of the fed snails and turning to values near to that of the control group at the end of the period of starvation analyzed (30 days). These authors proposed that the total protein content in the hemolymph of $B$. similaris raised on the tenth day of starvation due to lesions in the tissues of the snail in response to the physiological changes in the snail.

Mohamed and Ishak (1982) observed that in mitochondrial suspensions of starved Biom- 
TABLE

The L-aspartate:2-oxoglutarate aminotransferase (GOT) and L-alanine:2-oxoglutarate aminotransferase (GPT) activities in the hemolymph of Bradybaena similaris under starvation. Twenty five snails were used at each period analyzed

\begin{tabular}{ccc}
\hline $\begin{array}{c}\text { Time of starvation } \\
\text { (days) }\end{array}$ & $\begin{array}{c}\text { GOT activity } \\
\text { (URF/ml) X } \pm \text { SD }\end{array}$ & $\begin{array}{c}\text { GPT activity } \\
\text { (URF/ml) X } \pm \text { SD }\end{array}$ \\
\hline 0 (control group) & $19.367 \pm 0.9074^{a}$ & $22.467 \pm 0.4933^{a, b}$ \\
5 & $21.300 \pm 2.1630^{a, c}$ & $21.850 \pm 0.6364^{a, b}$ \\
10 & $100.05 \pm 0.0707^{b}$ & $21.300 \pm 0.3000^{a}$ \\
15 & $19.667 \pm 0.3215^{a}$ & $20.600 \pm 0.4243^{a}$ \\
20 & $18.867 \pm 1.3800^{a}$ & $21.733 \pm 0.8963^{a, b}$ \\
25 & $19.633 \pm 0.9292^{a}$ & $21.500 \pm 0.7000^{a}$ \\
30 & $17.800 \pm 0.3215^{a, d}$ & $23.567 \pm 1.0790^{a, b}$ \\
\hline
\end{tabular}

$\mathrm{X} \pm \mathrm{SD}$ : mean of five determinations \pm standard deviations; $a, b, c, d$ : means with significant difference among them $(\alpha=5 \%)$

phalaria alexandrina and Bulinus truncatus maintained, the oxygen consumption decreased. It was suggested that starvation exerts a direct influence on the stored energy of the snail to sustain normal metabolic processes. These changes showed that the starvation is responsible for the inhibition of the mitochondrial respiratory rate. The addition of glutamate and $\alpha$-ketoglutarate was not able to generate GTP which promotes conversion of oxalacetate to phosphoenol pyruvate. In consequence, they proposed that there must be an accumulation of oxalacetate, inhibiting GOT activity and limiting the importance of this enzyme in the gluconeogenesis pathway.

Thus, the results obtained in the present study corroborate the observations of Lira et al. (2000) showing that the increase in the GOT activity observed at the 10th day of starvation occurred due to lesions in the tissues of the snail, mainly in the digestive gland, decreasing after this period due to degradation by enzymes present in the hemolymph of the mollusc. Douglas and Haskin (1976) observed that in Crassostrea virginica infected with Minchinia nelsoni the GOT increase was associated to the destruction of the tissues of the gills.

The variation of the GPT activity seems to not be related to the alterations resulting from starvation, varying in a less significant way than the GOT activity.

\section{ACKNOWLEDGEMENTS}

To Dr Wellington da Silva Côrtes for the valuable suggestions to this manuscript.

\section{REFERENCES}

Becker W, Hirtbach E 1975. Effect of starvation on total protein and hemoglobin concentration in the haemolymph of Biomphalaria glabrata. Comp Biochem Physiol 51A: 15-16.
Becker W, Schmale H 1975. The nitrogenous products of degradation - ammonia, urea, and uric acid - in the hemolymph of the snail Biomphalaria glabrata. Comp Biochem Physiol A 51: 407-411.

Christie JD, Michelson EH 1975. Transaminase levels in the digestive gland-gonad of Schistosoma mansoniinfected Biomphalaria glabrata. Comp Biochem Physiol 50B: 233-236.

Douglas WR, Haskin HH 1976. Oyster-MSX interactions: alterations in hemolymph enzyme activities in Crassostrea virginica during the course of Minchinia nelsoni disease development. J Invertebr Pathol 27: 317-323.

El-Eman MA, Ebeid FA 1989. Effect of Schistosoma mansoni infection, starvation and molluscicides on acid phosphatase, transaminases and total protein and hemolymph of Biomphalaria alexandrina. $J$ Egypt Soc Parasitol 19: 139-147.

Joosse J, van Elk R 1986. Trichobilharzia ocellata: physiological characterization of giant growth, glycogen depletion, and absence of reproductive activity in the intermediate snail host, Lymnaea stagnalis. Exp Parasitol 62: 1-13.

Lira CRS de, Gomes EM, Chagas GM, Pinheiro J 2000. Influência do jejum severo sobre o conteúdo de proteínas totais e de amônio na hemolinfa de Bradybaena similaris (Férussac, 1821) (Gastropoda). Rev Bras Zool 17: 907-913.

Manohar L, Rao PV, Swami KS 1972. Variations in aminotransferase activity and total free amino acid level in the body fluid of the snail Lymnaea luteola during different larval trematode infection. $J$ Invert Pathol 19: 36-41.

Mohamed AM, Ishak MM 1982. Comparative effects of schistosome infection and starvation on the respiratory transport chain of the snails Biomphalaria alexandrina and Bulinus truncatus. Comp Biochem Physiol 71B: 289-292.

Moss DW, Henderson AR 1998. Enzimas. In CA Burtis ER Ashwood (eds), Tietz Fundamentos de Química Clínica, 4th ed., Guanabara Koogan, Rio de Janeiro, p. 275-325.

Nabih I, el Dardiri Z, el-Ansary A, Rizk M 1990. Mea- 
1164 Aminotransferases Activity in B. similaris - Jairo Pinheiro et al.

surement of some selected enzymatic activities on infected Biomphalaria alexandrina snails. Cell Mol Biol 36: 637-642.

Pinheiro J 1996. Influence of starvation on the glycogen and galactogen contents in the snail Bradybaena similaris (Férussac, 1821) (Mollusca, Gastropoda). Arq Biol Tecnol 39: 349-357.

Pinheiro J, Amato SB 1994. Eurytrema coelomaticum (Digenea, Dicrocoeliidae): the effect of infection on carbohydrate contents of intermediate snail host, Bradybaena similaris (Gastropoda, Xanthonychidae). Mem Inst Oswaldo Cruz 89: 407-410.

Reitman S, Frankel S 1957. A colorimetric method for the determination of serum glutamic oxalacetic and glutamic piruvic transaminases. Am J Clin Pathol
28: 56-63.

Schmale H, Becker W 1977. Studies on the urea cycle of Biomphalaria glabrata during normal feeding activity, in starvationand with infection with Schistosoma mansoni. Comp Biochem Physiol 58B: 321-330.

Stanislawski E, Becker W 1979a. Alterations of free amino acid content in the hemolymph of Biomphalaria glabrata (Pulmonata) in starvation and after infection with Schistosoma mansoni (Trematoda). Comp Biochem Physiol 63B: 477-482.

Stanislawski E, Becker W 1979b. Influences of semisynthetic diets, starvation, and infection with Schistosoma mansoni (Trematoda) on the metabolism of Biomphalaria glabrata (Gastropoda). Comp Biochem Physiol 63A: 527-533. 